\title{
LETTER TO THE EDITORS.
}

\section{SECONDARY HAMORRHAGE AFTER DIATHERMY OPERATIONS.}

The Editors,

Journal of Laryngology and Otology.

Dear Sirs,--In your April issue Dr E. A. Hallas, discussing the above question, makes the remark that "Dan McKenzie does not think the question " of secondary hæmorrhage after diathermy to be important.

Really! I must ask Dr Hallas for his authority for this, to me, most surprising statement. In all my publications on the subject of Surgical Diathermy in Cancer of the Pharynx I have insisted, time and again, upon the necessity for ligaturing the external carotid artery, not during nor after, but prior to the operation on the pharynx, in order to prevent secondary arterial hæmorrhage from the diathermy wound.

And by what stronger language (short of the linguistic excursions of the golfer) I could have emphasised more forcibly the importance to my mind of this step, I am quite at a loss to imagine.

May I add that, so far, I have not lost a single case from secondary hæmorrhage after diathermy, and, although I have seen severe venous bleeding during the separation of the sloughs, I have not yet met with any secondary arterial hæmorrhage at all. Venous hæmorrhage is controllable by clamp-pressure. Arterial hæmorrhage is not.-I am, Yours truly,

Dan MCKenzie.

March 1928.

\section{GENERAL NOTES}

\section{Royal Society of Medicine, I Wimpole Street, London, W. I.}

Section of Laryngology.-President, Mr Harold S. Barwell, F.R.C.S.; Hon. Secretaries, Mr W. M. Mollison, M.Ch., 23 Devonshire Place, London, W. $\mathrm{r}$, and Mr Lionel Colledge, F.R.C.S., 2 Upper Wimpole Street, London, W. r.

The next meeting of the Section will be held on Friday, 4th May, at 5 P.M. Members desirous of showing patients and specimens should communicate with the Senior Hon. Secretary, Mr W. M. Mollison.

Section of Otology.-President, Dr J. S. Fraser, F.R.C.S.E.; Hon. Secretaries, Mr Alexander R. Tweedie, F.R.C.S., I 4 Oxford Street, Nottingham, and Mr Nicol M. Rankin, M.B., 56 Harley Street, London, W. I.

The next Meeting of the Section will be held on Saturday, 5th May, at I0.30 A.M. Members desirous of showing patients and specimens should communicate with the Senior Hon. Secretary, Mr Alex. R. Tweedie.

The Sections of Laryngology and Otology will hold their Summer $38 \mathrm{I}$ 